\title{
4: $123102497-123096130$
}

National Cancer Institute

\section{Source}

National Cancer Institute. 4:123102497-123096130. NCI Thesaurus. Code C41880.

Physical location of CCNA2_Gene 